\title{
Shoreline Change Analysis in Demak, Indonesia
}

\author{
Komariah Ervita, Muh Aris Marfai \\ Faculty of Geography, Universitas Gadjah Mada, Yogyakarta, Indonesia \\ Email: arismarfai@ugm.ac.id
}

How to cite this paper: Ervita, K. and Marfai, M.A. (2017) Shoreline Change Analysis in Demak, Indonesia. Journal of Environmental Protection, 8, 940-955. https://doi.org/10.4236/jep.2017.88059

Received: June 7, 2017

Accepted: July 25, 2017

Published: July 28, 2017

Copyright (C) 2017 by authors and Scientific Research Publishing Inc. This work is licensed under the Creative Commons Attribution International License (CC BY 4.0).

http://creativecommons.org/licenses/by/4.0/ (c) (i) Open Access

\begin{abstract}
Demak Regency is located in Central Java Province Indonesia bordering the Java Sea. Intense activities in the coastal area of Demak have caused changes in the shoreline. This paper aimed to determine the shoreline change for 25 years and to identify the major factors that influenced those changes in the coastal area of Demak. A shoreline change analysis was conducted based on Multitemporal Landsat satellite imagery with sensors of Thematic Mapper (TM), Enhanced Thematic Mapper plus (ETM+), and Operational Land Imager (OLI). This study used the data from multitemporal Landsat imagery of year 1990, 1994, 1999, 2002, 2008, 2011, and 2015. Identification of the shoreline was performed through band ratio, histogram threshold, and composite band 457 methods. An erosion and accretion analysis has been done using the wind data via the processing of Wind Rose Plot (WRPLOT), wave prediction using Sverdrup Munk Bretschneider (SMB) method, tide data processing to know the value of Mean High Water Level (MHWL), Mean Sea Level (MSL), Mean Low Water Level (MLWL), and Lowest Low Water Level (LLWL), as well as currents data processing that has been implemented to achieve the goal. The research results showed that the shoreline change in Demak Regency was quite distinct compared to several previous years due to erosion and accretion processes. The greatest shoreline change happened in Sayung District and Wedung District. Sayung District was likely to experience erosion process while Wedung District tended to show accretion process. Several physical factors that became the major influence on these changes were the wind, waves, currents, and tides.
\end{abstract}

\section{Keywords}

Shoreline Dynamics, Erosion, Accretion, Demak Regency, Indonesia

\section{Introduction}

Republic of Indonesia is the largest archipelagic state in the world comprising 13,000 large and small islands as well as possessing more than 99,093 km of 
coastal areas (14\% of the world shorelines) with approximately $60 \%$ of its inhabitants living on the coast [1] [2] [3]. Along these Indonesian shorelines, coastal areas are established with a variety of typologies and characteristics. This coastal configuration is possibly caused by natural and non-natural (human activities) processes and activities in both the land and the sea [4] [5]. One of the natural processes from the sea known as the hydro-oceanographic process may have an influence in the form of wave pounding, ocean current patterns, and tidal phenomena that are sometimes affected by climate change [6] [7]. In addition, the natural process from the land, such as erosion or sedimentation, also affects coastal areas [8]. From the geomorphological point of view, the dynamics process of coasts has in fact established unique and varied coastal landscapes.

Along with the increasing number of population, the needs for land for human purposes also rise. Coastal areas are rich in potential resources making them become highly strategic to develop, such as for settlement, industry, tourism, and fishery activities [9] [10] [11] [12]. The needs for land have often been fulfilled through land-use change and reclamation. Lands previously functioned as rice fields, fishpond, or mangrove forests that have been changed into settlement areas. This has not been merely about settlement but because of the abundant coastal resources that are expected to be able to fulfill the economic needs of the inhabitants. In addition, to support the development of coastal areas, adequate infrastructure, such as ports and piers, has been built. The development activities conducted in coastal areas as well as natural factors have led to highly complex problems [13]-[18]. These natural factors are related to the morphodynamic aspect, an aspect that describes the exogenetic processes relating to the activities of water, wind, gravity, and glacier, which in this case were influenced by the activities of wind, currents, waves, and tides [6] [11]. One of the problems in coastal areas which become a major concern is shoreline change [7]. The shoreline change can be in the form of advancing (sedimentation/accretion) and retreating (coastal erosion) shorelines [19]. The erosion and sedimentation are caused by two activities including natural activities due to currents, waves, and wind as well as human activities in the form of land clearing and over-exploitation of resources in coastal lands [8] [20] [21].

Demak Regency is one of the regencies in the northern part of Central Java Province that directly borders the Java Sea. The regency is 89.743 ha in area and directly borders Semarang City as the center of government and economy in Central Java, so it is highly potential as the buffer zone of the economy in Central Java [22]. Due to this high activity and many land using purposes on the coastal area and supported by flat topography with 0 up to $3 \%$ slope angle, various coastal problems are found in this region. Erosion activities in coastal areas are increasing in some parts, and as a counterbalance to erosion, accretion or sedimentation phenomena will occur, causing the appearance of new lands in other parts [8]. The districts experiencing erosion and sedimentation (accretion) in Demak Regency include Sayung, Bonang, and Wedung [23]. The total extent of 
erosion along the coastal regions of Demak Regency has reached 495.80 ha. The impacts include the damage of mangrove ecosystem, settlement, and fishponds that become economic sources of the local inhabitants, the decrease in the number of coastal resources, as well as the social, economic, and environmental changes in the region [19] [24].

According to [25], the complex problems in coastal areas have made the regions become the priority of sustainable coastal management and monitoring program. Remote sensing technology and Geographic Information System is considered as an inexpensive and appropriate method to provide data that have developed quite rapidly particularly in coastal and marine sciences [8]. Remote sensing technology is often used not only for planning but also for monitoring among others shoreline changes relating to coastal area development planning [26]. The use of remote sensing image dataset, such as Landsat and Geographic Information System, plays an important role in the process of coastal area monitoring, especially in shoreline extraction because of the multitemporal data availability [7] [25] [27] utilized the Landsat Thematic Mapper (TM) and Enhanced Thematic Mapper plus (ETM+) imagery to monitor the geomorphological changes in the coastal area of Hendijan Delta in Iran. In addition, reference [23] used the multitemporal satellite data from the Landsat Multispectral Scanner System (MSS) and Landsat Enhanced Thematic Mapper plus (ETM+) imagery to monitor the changes in Wulan Delta, in Demak Regency, Indonesia. Meanwhile, reference [7] benefited from Landsat Thematic Mapper (TM) and Enhanced Thematic Mapper plus (ETM+) multitemporal data to border the land and the sea areas as well as to map the spatial variety due to wave power. A lot of data processing techniques can be used to monitor changes, including visual interpretation technique, spectral value interpretation by observing Digital Number (DN) value, and composite band technique [15]. Analysis of Digital Number (DN) value was also utilized to process the Landsat imagery data in the research conducted by [28]. In Indonesia, many studies about shoreline changes in the coastal areas of Central Java's north coast using remote sensing technique and GIS have been performed, for example by [15] [29] [30] [31].

\section{Study Area}

Demak regency is 89,743 ha in area and divided administratively into 14 destrict consisting of 243 villages (desa), 6 urban communities (kelurahan), and 512 hemlets (dusun) [32]. The four districts directly bordering the Java Sea are Sayung District, Karangtengah District, Bonang District, and Wedung District. Figure 1 illustrates the location of Demak Regency that geographically lies between $110^{\circ} 27^{\prime} 58^{\prime \prime} \mathrm{E}$ to $110^{\circ} 48^{\prime} 47^{\prime \prime} \mathrm{E}$ Longitude and $6^{\circ} 43^{\prime} 26^{\prime \prime S}$ to $7^{\circ} 09^{\prime} 43^{\prime \prime S}$ Latitude. The types of land use in Demak Regency include rice fields (56.74\%), moors/ farms $(14.9 \%)$, settlements $(12.98 \%)$, fishponds $(7.89 \%)$, forests $(2.05 \%)$, and others (5.44\%) [32]. The northern part of Demak Regency has a lower topography with $0-3 \mathrm{~m}$ elevation, while the southern part is extremely higher with more than $100 \mathrm{~m}$ elevation. 

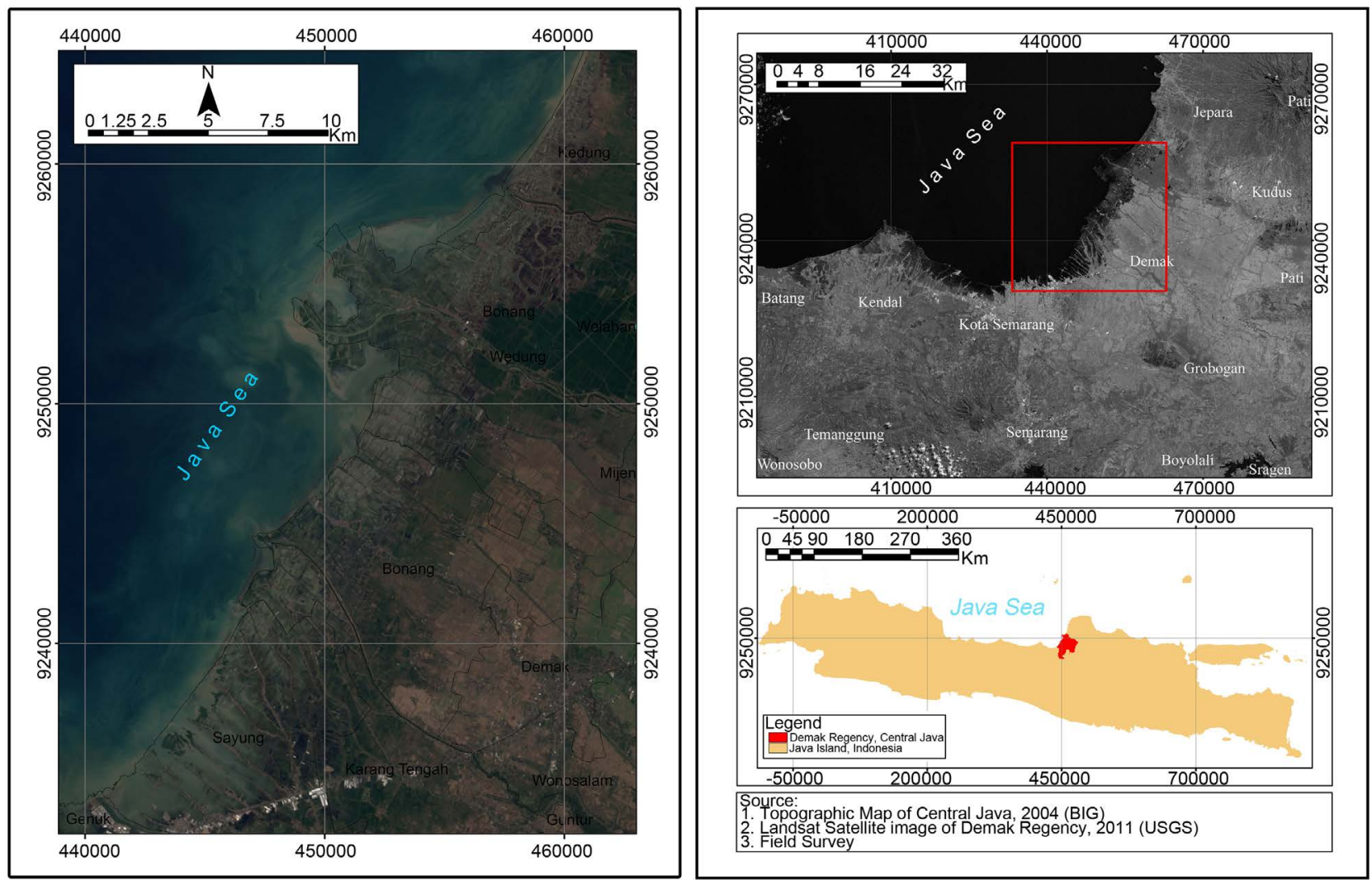

Figure 1. The location of demak regency, Indonesia.

\section{Material and Methods}

The research was conducted in the four districts directly bordering the Java Sea, which are Sayung District, Bonang District, Wedung District, and Karangtengah District. The data processing method involved shoreline extraction and analysis of the oceanographic characteristics including the winds, waves, currents, and tides. The shoreline extraction itself was performed through an on-screen digitizing technique. To conduct a proper and accurate digitizing process, the collected data were visually interpreted using the image enhancement technique. Due to the availability of the good image quality data, this study used the data only from multitemporal Landsat imagery of year 1990, 1994, 1999, 2002, 2008, 2011, and 2015. Among the commonly used image-enhancement approaches are spatial filtering, histogram equalization, composite band, classification, density slicing, image processing software from UNESCO (BILKO method), and Australian Geological Survey Organization (AGSO) algorithm method [33] [34]. Image enhancement covers all operations that produce a new image with distinctive visual appearance and spatial characteristics [33]. In this research, the image enhancement approaches used were rationing (band ratio), Red Green Blue (RGB) composite, and histogram equalization. Rationing (band ratio) is an approach that combines two bands or more in order to obtain the desired information based on the characteristics of each involved band. The band ratio method used here was band 4 with band 2 (b4/b2), band 5 with band $2(\mathrm{~b} 5 / \mathrm{b} 2)$, 
and band 7 with band 2 (b7/b2) [34]. Band 4 was utilized to obtain information about the shorelines covered by vegetation, while band 5 and band 7 were used to collect information about the shorelines covered by soil and rock. Meanwhile, the RGB composites or band combination methods involved in shoreline visual interpretation were RGB 453, RGB 147, RBG 457, and RGB 321. Apart from these two methods, the shoreline delineation method using histogram threshold was employed as well. This method distinguishes the borders of water and land by modifying the pixel value in the histogram until a specific value describing vividly the land and the water is obtained.

An analysis of oceanographic characteristics was performed by processing the wind data obtained from the maritime meteorology and geophysics station (Badan Meteorologi, Klimatologi, dan Geofisika or BMKG) of Semarang using the Windrose software. The wave data were analyzed through the Sverdrup Munk Bretschneider (SMB) method. This the Sverdrup Munk Bretschneider (SMB) method considers the fetch length or distance of blowing winds in which the length is influenced by the wind height and speed that form waves and currents. Fetch is the length of winds that blow without hindrance to generate waves and assumed to have relatively constant wind speed and direction [35] [36]. In addition, the data of tides were analyzed using graphs of tide levels to determine the Mean High Water Level (MHWL), Mean Sea Level (MSL), Mean Low Water Level (MLWL), and Lowest Low Water Level (LLWL).

\section{Result and Discussion}

\subsection{Shoreline Extraction}

The shoreline identification in this study was conducted through visual interpretation towards the object appearance. This visual interpretation was resulted from image enhancement using band ratio and composite band methods. Meanwhile, the histogram threshold method is a derivative of band ratio method. The combination of these three methods will result in more accurate shoreline extraction. The method combination was chosen because each method has its own weaknesses. For example, the weakness of composite band method is that it requires longer time to conduct on-screen digitizing of object appearance in images. The histogram threshold method can help facilitate the on-screen digitizing process by manually observing the spectral value of each image to separate the land and the sea areas as clearly as possible only by considering the image's spectral value. The spectral value is then divided into 0 and 1 , in which 0 describes the sea area and 1 represents the land area (Figure 2).

The shoreline extraction through a band ratio method using band 4/2, 5/2, and $7 / 2$ provides different results. Band 4 gives information about the shorelines covered with vegetation, while band 5 and 7 inform about soil and rock. Band ratio $4 / 2$ would then provide clearer information about the border between the land and the sea compared to that from band $5 / 2$ and $7 / 2$. This is because band 4 is an infrared wave with $0.75 \mu \mathrm{m}-0.90 \mu \mathrm{m}$ wavelength that results in darker color for water objects. Meanwhile, band ratios 5/2 and 7/2 are also an infrared 


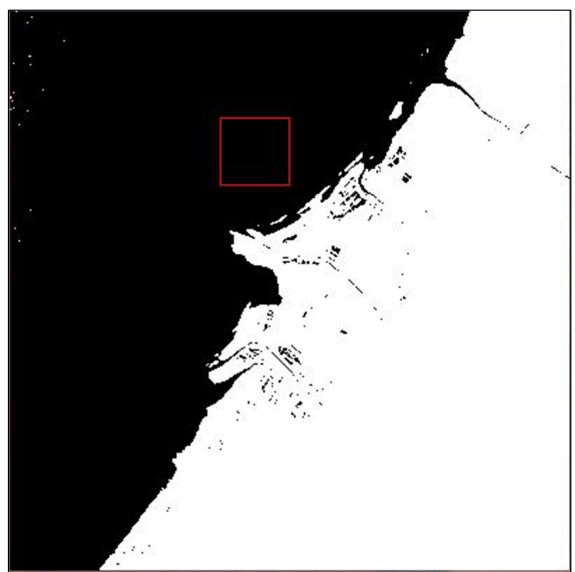

Disp \#1 (5684.1853) Scm: R:0 G:0 B:0 Projection: UTM, Zone 49 South Map: 443775.00E.9247855.00S Meters LL: $6^{\circ} 48^{\prime} 15.49^{\prime \prime} S .110^{\circ} 29^{\prime} 28.20^{\prime \prime} \mathrm{E}$ Data: 0

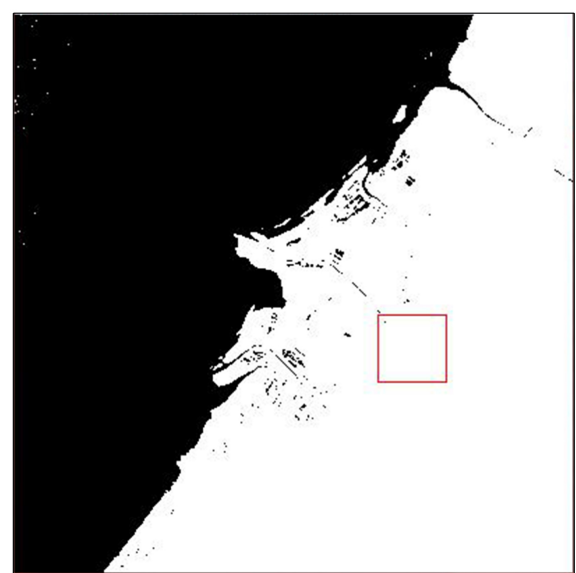

Disp \#1 (5950.1957) Scm: R:255 G:255 B:255 Projection: UTM, Zone 49 South Map: 451755.00E.9244735.00S Meters LL: $6^{\circ} 49^{\prime} 57.35^{\prime \prime S}$. $110^{\circ} 33^{\prime} 48.09^{\prime \prime} \mathrm{E}$ Data: 1

Figure 2. Results of Landsat ETM imagery processing using the histogram threshold method in which 0 represents the sea (left) and 1 describes the land (right).

wave with $1.55 \mu \mathrm{m}-1.75 \mu \mathrm{m}$ and $2.08 \mu \mathrm{m}-2.35 \mu \mathrm{m}$ known as mid-infrared and far-infrared. Both band ratios are better at recognizing soil and rock objects in the land, so they were utilized to clarify the borders between the land and the sea that had been located by band ratio $4 / 2$. Therefore, the borders between the land and the sea would be much clearer.

The histogram stretching for each band ratio gave various results because of the value range of each band ratio that would eventually affect the maximum and minimum values in the histogram stretching process. The histogram stretching between the land and the sea is shown by the valley between two peaks that represent the range of pixel value or the mixed range of wet area at the meeting point of the land and the sea. The separation of reflectance value in the histogram was performed using the higher and lower values that would then produce a value as the border between the land and the sea (Figure 3 ).

The histogram stretching for band ratio $4 / 2$ resulted in better separation of land and sea objects, so it would be used in the following shoreline extraction and compared with the Red Green Blue (RGB) composite method. This shoreline extraction was automatically performed by the polygon-to-line tools in the arcGIS software. The digitizing process was aided by the composite band 457 . The result of this automatic digitizing could not be directly used because it should follow a selection process. The composite band used here was composite 457. It is a false color composite or unreal color on the earth surface. Composite 457 is excellent at interpreting coastal objects and shorelines. While band 4 is used to obtain information about shorelines covered with vegetation, each of band 5 and band 7 is utilized to inform about the shorelines covered by soil and rock. Composite 457 will show bluish green on soil objects and orange on vegetation objects. Sea objects will be black because of the near and mid-infrared 

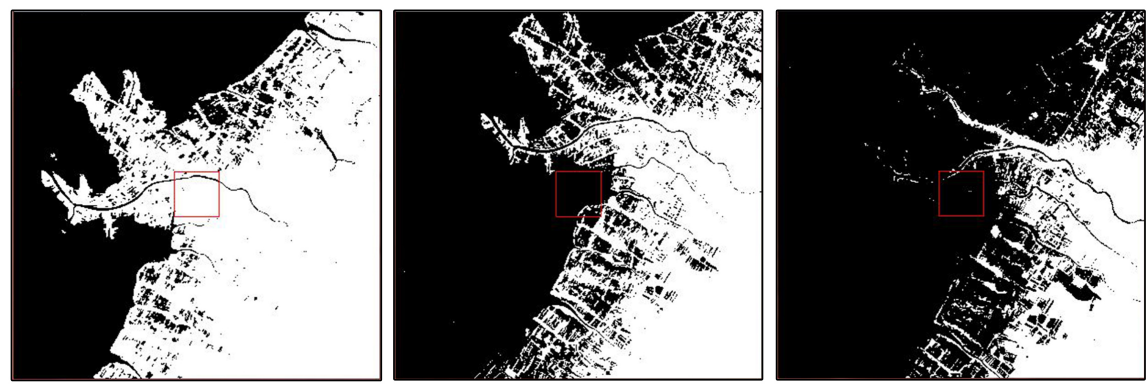

Figure 3. The masking process of Landsat ETM+ imagery using band 4 (left), band 5 (middle), and band 7 (right).

wave so that the appearance of water and water body containing mud will be well interpreted. This composite band will help further interpretation of the shoreline manual digitizing in the arcGIS software. The manual digitizing will provide information about the shoreline change that has been in line with the field validation result.

\subsection{Shoreline Change in Demak}

The shoreline extraction using band ratio, histogram threshold, and composite band 457 methods showed that at intervals of 25 years there have been significant changes in Demak Regency. Most changes occurred in Sayung District and Wedung District. The shoreline change in Sayung District was dominated by intensive erosion process since 1994 up to the present, while accretion process occurred mostly in Wedung District (Figure 4). Based on the result of interviews with local inhabitants of Sayung District, the current distance between the houses and the sea is now $\pm 1 \mathrm{~km}$, while in 1990s the distance reached $\pm 4 \mathrm{~km}$. In 2008 , the shoreline in Sriwulan Village continued to retreat to the land and almost reached the main road, which is the major transport route in Java Island, while in the northeast, the shoreline change spread more extensively through Rejosari Hamlet in Bedono Village of Sayung District. Six years after 2002, Rejosari Hamlet sank, and the inhabitants were relocated to other villages. The extent of the change continued to expand from 2011 to 2015.

An accretion process occurred frequently in Wulan Delta in Berahan Kulon Village. From 1990, 1994, 1999, 2002, 2008, 2011 and 2015, Wulan Delta had formed a new branch to its left side directing to the south. This area expansion was due to the location that is close to the river, which also showed that this expansion was influenced by the morphodynamic development of estuary. The expansion of Wulan Delta can be seen in Figure 5. Meanwhile, erosion and accretion processes have also occurred in Karangtengah District and Bonang District leading to a shoreline change. Yet, the process was quite insignificant that it did not have such a massive impact as what happened in Sayung District and Wedung District.

\subsection{Oceanic Condition}

Based on the maximum wind data for 2002-2012 from the maritime meteorology, 


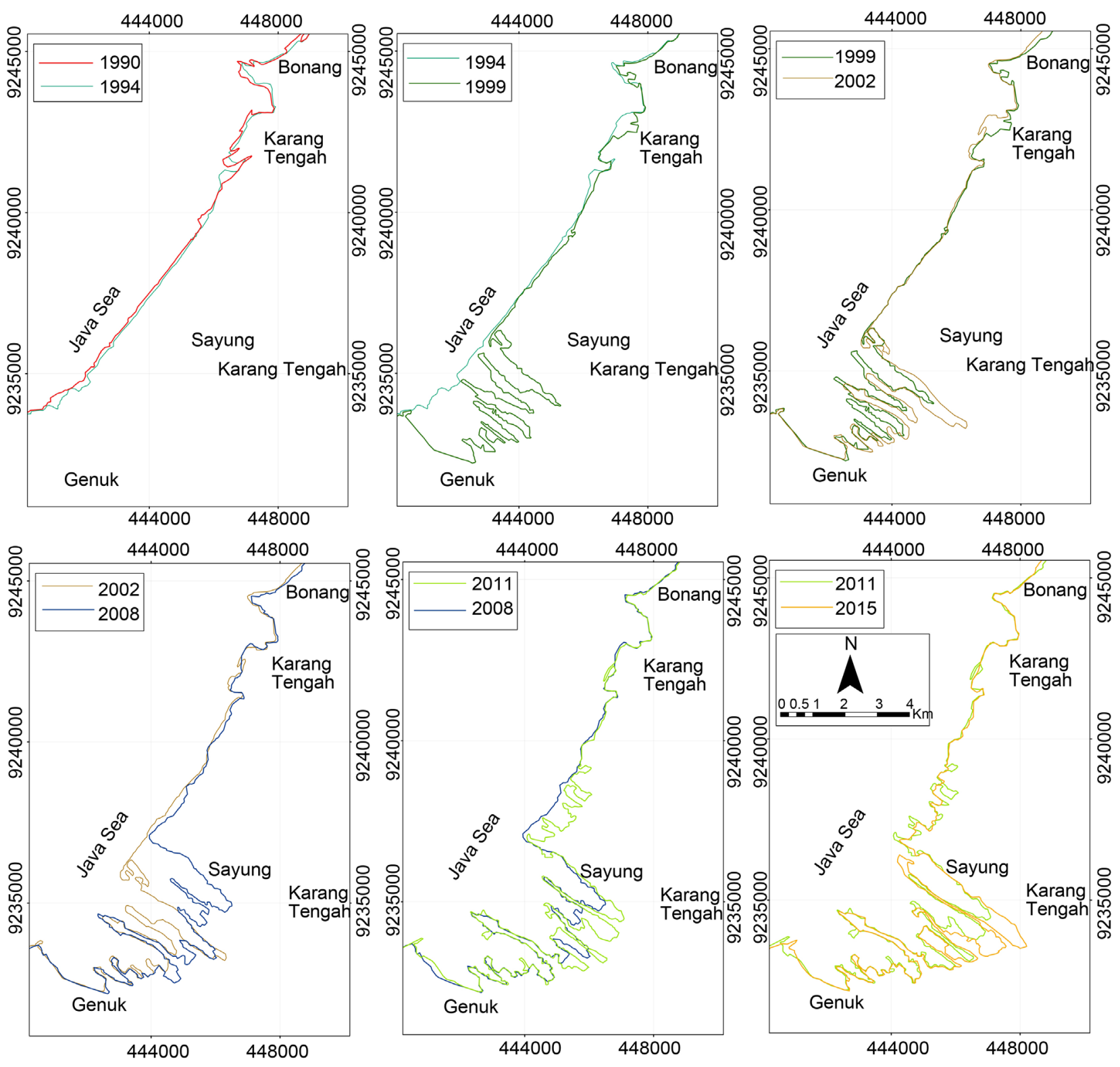

Figure 4. The shoreline change in Sayung District and Karangtengah District in 1990, 1994, 1999, 2002, 2008, 2011 , and 2015.

climatology, and geophysics station of Semarang (BMKG), the winds blew from various directions with a variety of speeds and strengths. During the decade, the wind mostly blew from the east with $36.75 \%$ frequency. In addition, the wind also blew from the northwest (20.69\%), north (16.72\%), and west (12.39\%). Exactly $50 \%$ of the winds dominantly blew at a speed of $7-11$ knots. Meanwhile, $32.63 \%$ winds reached a speed of $11-17$ knots. Gales at a speed of $>34$ knots had occurred four times $(0.1 \%)$. The condition of the winds in every season from 2002 to 2012 is described in Figure 6 and Figure 7.

Demak Regency is generally influenced by the monsoon climate that has four seasons in a year, which are the west monsoon, the first transitional season, the east monsoon, and the second transitional season. The west monsoon lasts from December to February with the transitional season in March up to May. On the 

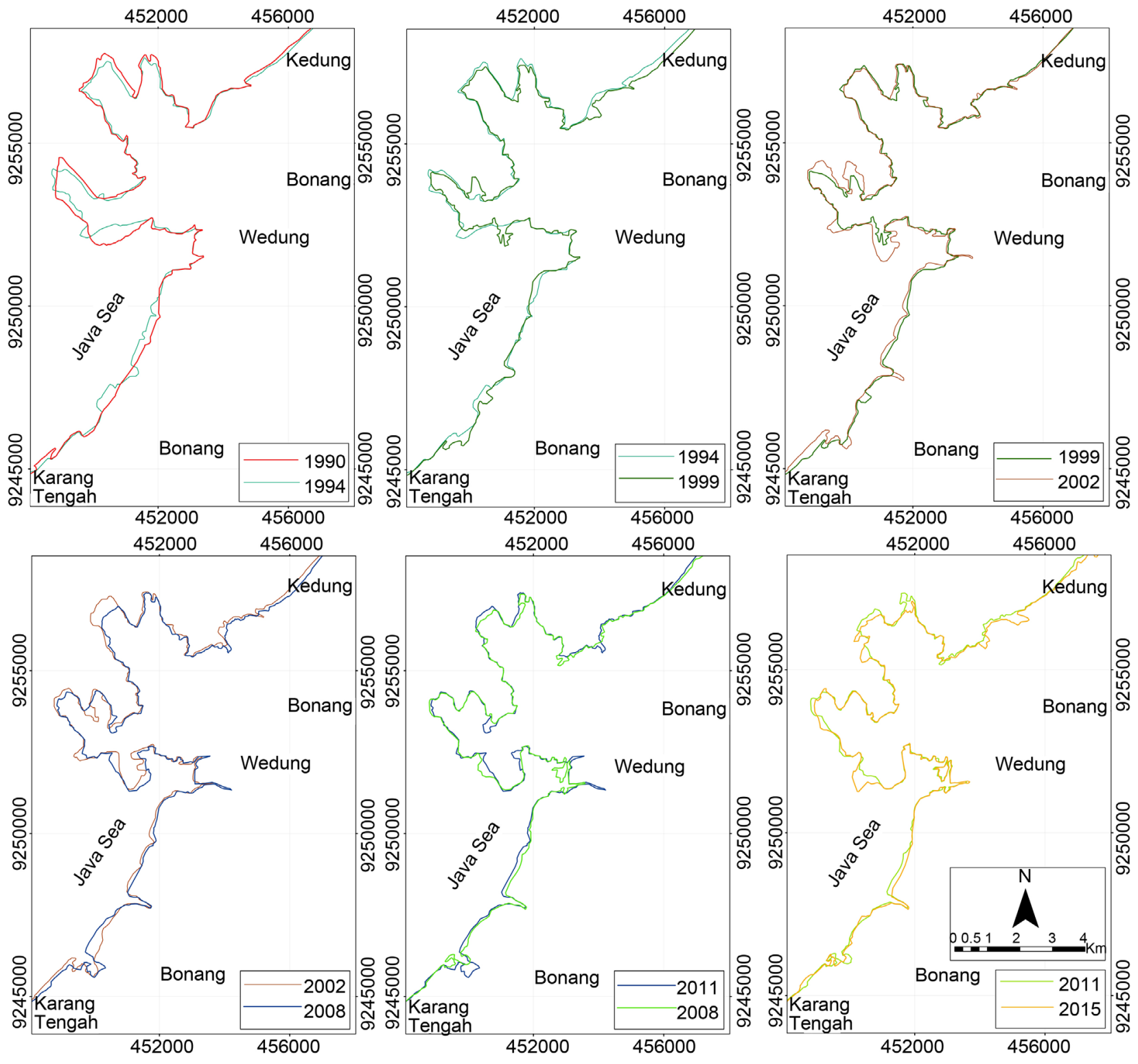

Figure 5. The shoreline change in Bonang District and Wedung District in 1990, 1994, 1999, 2002, 2008, 2011 , and 2015.

other hand, the east monsoon lasts between June and August with the transitional season from September to November. The Windrose diagram describes the dominant winds during the west monsoon blowing from the west $(32.19 \%)$ and northwest (31.69\%) at a speed of $7-11$ knots (40.26\%). The condition of the west season is discribed in Figure 6(a). During the first transitional season, the winds mostly blew from the east (31.57\%), north (18.82\%), and northwest (18.63\%) (Figure 6(b)). The dominant wind speed was 7 - 11 knots (60.86\%) with one time occurrence $(0.1 \%)$ of gale ( 28 - 34 knots). In the east monsoon (Figure 7(a)), the winds dominantly came from the east (62.61\%) at a dominant speed of $7-11$ knots as much as $56.18 \%$ and a speed of $4-7$ knots with $12.46 \%$ frequency. During the second transitional season, the winds blew mostly from the east (37.34\%), northwest (24.82\%), and north (20.72\%) (Figure 7(b)). The 


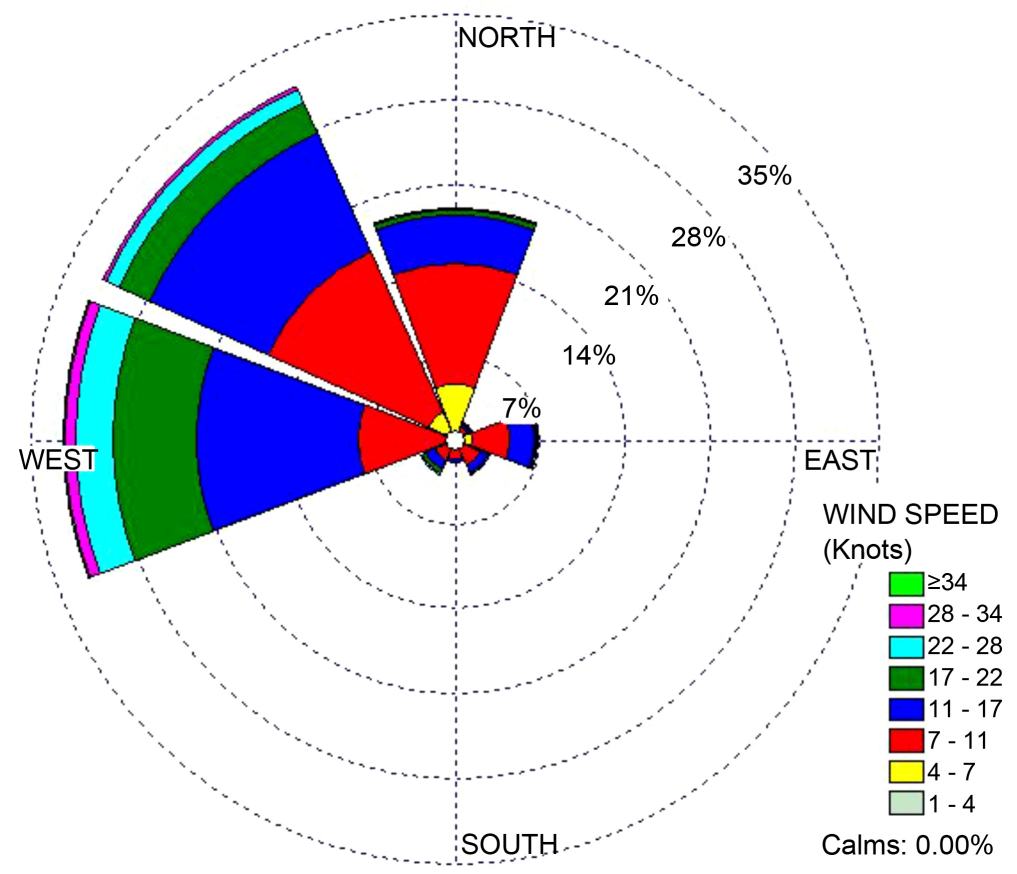

(a)

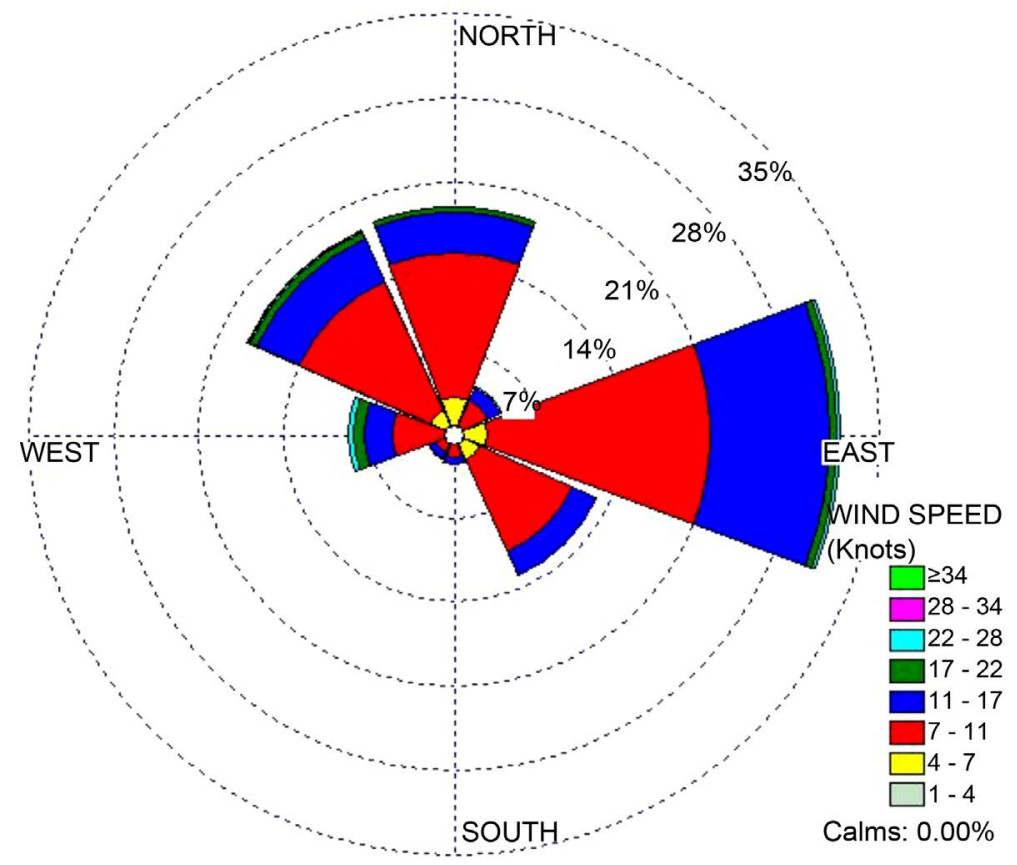

(b)

Figure 6. The Windrose diagram of the winds blowing during the west (a) and the first transitional (b) seasons of 2002-2012 in the coastal areas of Demak Regency, Indonesia.

dominant wind speeds were 11 - 17 knots (44.45\%) and 7 - 11 knots (42.34\%).

The ocean wave analysis using Sverdrup Munk Bretschneider (SMB) method indicated that the waves were generated by the average wind speed blowing from the west and northwest at $1-3 \mathrm{~m}$ of height. In the same season, the wave height could reach 3 - 7 me with maximum wind speed. Besides in the west monsoon, 


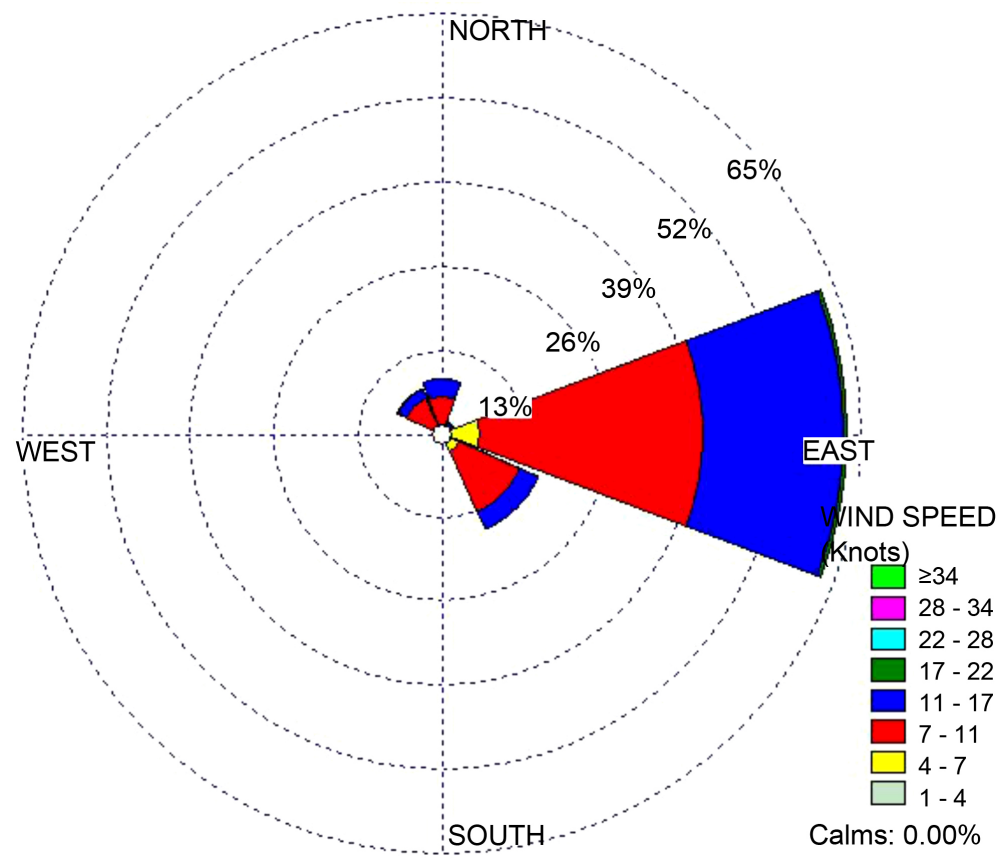

(a)

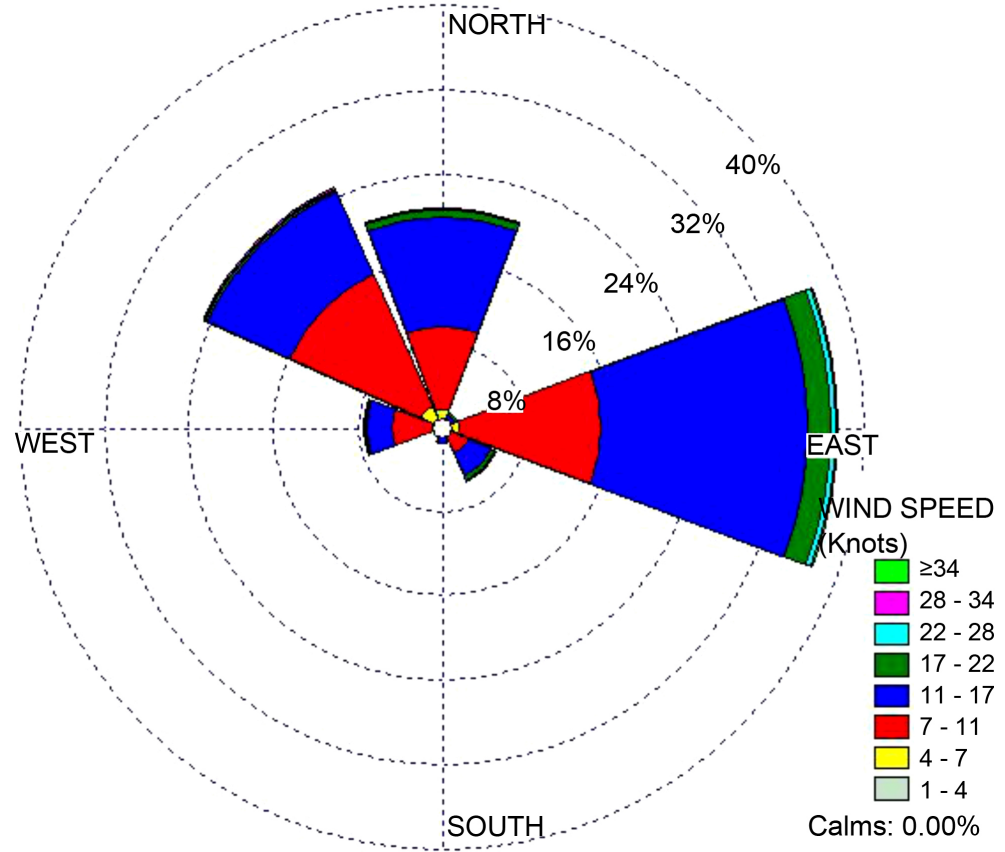

(b)

Figure 7. The Windrose diagram of the winds blowing during the east (a) and the second transitional (b) seasons of 2002-2012 in the coastal areas of Demak Regency, Indonesia.

high waves also frequently occurred in the second transitional season. Meanwhile, the ocean waves in the first transitional season and east monsoon were not as high because of the transition from rainy season to dry season so that the influence of winds was not so strong, and the waves were not as high as in the west monsoon and second transitional season. 
Based on the data from BMKG of Semarang, the current speed increased every year with the dominant direction from the west and northwest in the east monsoon and from the east, southeast and northeast during the west monsoon. The calculated currents were the sea-surface currents generated by winds. The current speed in the west monsoon, as much as $5-13.4 \mathrm{~cm} \cdot \mathrm{s}^{-1}$, was lower than that during the east monsoon which reached $5-25 \mathrm{~cm} \cdot \mathrm{s}^{-1}$. The power of wind on the sea-surface layer could generate a surface current whose speed was $3 \%$ of the wind speed itself. Therefore, the generated current speed was insignificant. The influence of earth rotation or Coriolis force caused the currents to move to a direction different from the wind direction. The current would generally be directed to the right of the wind direction in the northern hemisphere and to the left in the southern hemisphere. Therefore, during the west monsoon and first transitional season, the winds were likely to blow from the west and northwest. The formed currents moved to a different direction and tended to move to the east, southeast, and southwest, while in the east monsoon, the current direction came from the west, northwest, and north.

The calculation of Formzahl (F) number showed that the type of tides in the research area was a mixed tide prevailing diurnal with $\mathrm{F}$ of 1.67. It means that in one period of tides ( 24 hours), there is one high tide and one low tide, but sometimes two high tides and two low tides occur with different heights and periods. According to the tide forecast graph from the Maritime BMKG Station of Semarang in 2002-2012, the Mean Sea Level (MSL) was $59 \mathrm{~cm}$ with a Mean High Water Level (MHWL) of $99 \mathrm{~cm}$ and $31 \mathrm{~cm}$ Mean Low Water Level (MLWL). During 2002-2012, the Highest High Water Level (HHWL) reached $238.6 \mathrm{~cm}$ while the lowest was $3.6 \mathrm{~cm}$.

\subsection{Erosion and Accretion}

In general, a significant shoreline change has occurred along the coastal areas of Demak Regency. Sayung District was one of the districts in Demak Regency that experienced the greatest shoreline change directing to the land. It means the erosion process in Sayung District was quite significant. A massive land-use change in Sayung District made the greatest contribution to the shoreline change in this area. In addition, the harbor construction and continuous reclamation in Semarang coast had changed the current direction, ocean waves, and coastal sedimentation in Demak Regency. According to [37], the largest erosion in Sayung District occurred in Bedono Village reaching 96.96 ha followed by Sriwulan Village (75 ha), Timbulsloko Village (30 ha), and Surodadi Village (30 ha). Reference [30] mentioned that the erosion speed in Demak Regency from 2006 to 2009 reached $156.98 \mathrm{~m}$ for 4 years or as fast as $52.33 \mathrm{~m}$ a year, while the accretion rate was $123.43 \mathrm{~m}$ for 4 year or approximately $41.14 \mathrm{~m}$ a year.

Wedung District is another district in Demak Regency that indicated a significant shoreline change in the last 25 years can be seen in Figure 5. This shoreline change was mainly caused by the accretion in Wulan Delta and erosion in the northern part of Wulan Delta. For 25 years, Wulan Delta has developed a dominant 
branch to its left side directing to the west-south. This change was due to suspended material sedimentation from the upstream of Wulan River. Based on [38], the area of Wulan Delta was 13059.82 ha in 2010, while in 2002 it was 13 064.82 ha. During the period, the area extent had decreased by 4.41 ha due to a natural factor, which were high waves hitting in 2005.

\section{Conclusion}

The shoreline of Demak Regency during the period of 1990-2015 has significantly changed mainly because of erosion and accretion process. Erosion process occurred mostly in Sayung District causing several hamlets to sink and inhabitants to relocate. Erosion process was also experienced by Karangtengah District and Bonang District although the area and impact were not as significant as in Sayung District. Meanwhile, most of the accretion process occurred in the estuary indicating the existence of headwaters material sedimentation carried by the river flow and deposited in the downstream, which was in the coastal area. This shoreline change was caused by natural factors such as winds, waves, currents, and tides worsened by human interventions. The wind directions and generated waves mostly come from the northwest and north moving perpendicularly to the coast causing higher pressure to it. From 2002 to 2012, the wind blew at a speed of 7 - 11 knots as much as $50 \%$ and $39.24 \%$ reached the speed of $\geq 11$ knots from the east, northwest, and north. The tides in the coastal areas of Demak Regency indicated a rise in the sea water level. The mean sea level (MSL) in 2002-2012 in Demak Regency was $59 \mathrm{~cm}$ with a mean high water level (MHWL) of $99 \mathrm{~cm}$ and $31 \mathrm{~cm}$ mean low water level (MLWL). From 2002 to 2012, the highest high water level (HHWL) was $238.6 \mathrm{~cm}$ occurring in 2009 while the lowest reached $3.6 \mathrm{~cm}$ in 2002. The innovation of this research is the implementation of a combination of satellite image data analysis methods to map shoreline changes. This study used band ratio method, threshold histogram method, and composite band method. The meaning of this research is very important in the context of monitoring the coastal environment especially in Demak Regency which is very lack for the availability of data. This shoreline change is thought to be closely related to wind, wave, current, and tidal factors. For that in this study these factors are discussed more deeply. However, further this study is still needed in the next step to prove the relevance of each factor, as a recommendation of this research.

\section{Acknowledgements}

Part of this paper is developed from bachelor thesis of the first author. This paper is also part of the International Research Collaboration program from the Ministry of Research, Technology and Higher Education of Indonesia on Ecosystem based Disaster Risk and Reduction (Eco-DRR) No. 2244/UN1.P.III/ DIT-LIT/LT/2017.

\section{References}

[1] Dahuri, R., Rais, J., Ginting, S.P. and Sitepu, M.J. (1996) Integrated Coastal and Ma- 
rine Resource Management (in bahasa). Pradnya Paramitha, Jakarta.

[2] Sunarto. (2008) The Nature of Coastal Disaster in Geomorphological Perspective and Efforts to Reduce The Risk. Indonesian Disaster Journal, 3, 9-16.

[3] Badan Informasi Geospasial (BIG). (2013) The Integrated Geospatial Information for Better Indonesia.

http://www.bakosurtanal.go.id/berita-surta/show/ig-yang-terintegrasi-untuk-indon esia-yang-lebih-baik

[4] Supriyanto, A. (2003) Coastal Abrasion Analysis and Alternative Countermeasures in Coastal Area of Kendal-Semarang Regency. Thesis, Program Pascasarjana Universitas Diponegoro, Semarang. (In Bahasa)

[5] Gopinath, G. (2010) Critical Coastal Issues of Sagar Island, East Coast of India. Environmental Monitoring and Assessment, 160, 555-561.

https://doi.org/10.1007/s10661-008-0718-3

[6] Sunarto, Marfai, M.A. and Setiawan, M.A. (2014) Geomorphology and Coastal Dynamics of Jepara. Gadjah Mada University Press, Yogyakarta.

[7] Kaliraj, S., Candrasekar, N. and Magesh, N.S. (2015) Evaluation of Coastal Erosion and Accretion Processes along the Southwest Coast of Kanyakumari, Tamil Nadu Using Geospatial Techniques. Arabian Journal of Geosciences, 8, 239-253.

https://doi.org/10.1007/s12517-013-1216-7

[8] Natesan, U., Thulasiraman, N., Deepthi, K. and Kathiravan, K. (2013) Shoreline Change Analysis of Vedaranyam Coast, Tamil Nadu, India. Environmental Monitoring and Assessment, 185, 5099-5109. https://doi.org/10.1007/s10661-012-2928-y

[9] Marfai, M.A., King, L., Sartohadi, J., Sudrajat, S., Budiani, S.R. and Yulianto, F. (2008a) The Impact of Tidal Flooding on a Coastal Community in Semarang, Indonesia. Environmentalist, 28, 237-248. https://doi.org/10.1007/s10669-007-9134-4

[10] Kesgin, B. and Nurlu, E. (2009) Land Cover Changes on the Coastal Zone of Candarli Bay, Turkey Using Remotely Sensed Data. Environmental Monitoring and Assessment, 157, 89-96. https://doi.org/10.1007/s10661-008-0517-X

[11] Sesli, F.A., Karsil, F., Colkesen, I. and Akyol, N. (2009) Monitoring the Changing Position of Coastlines Using Aerial and Satellite Image Data: An Example from the Eastern Coast of Trabzon, Turkey. Environmental Monitoring and Assessment, 153, 391-403. https://doi.org/10.1007/s10661-008-0366-7

[12] Mujabar, P.S. and Candrasekar, N. (2013) Shoreline Change Analysis along the Coast between Kanyakumari and Tuticorin of India Using Remote Sensing and GIS. Arabian Journal of Geosciences, 6, 647-664. https://doi.org/10.1007/s12517-011-0394-4

[13] Marfai, M.A. and King, L. (2007) Monitoring Land Subsidencein Semarang, Indonesia. Environmental Geology, 53, 651-659. https://doi.org/10.1007/s00254-007-0680-3

[14] Marfai, M.A. and King, L. (2008) Potential Vulnerability Implication of Coastal Inundation Due to Sea Level Rise for the Coastal Zone of Semarang City, Indonesia. Environmental Geology, 54, 1235-1245. https://doi.org/10.1007/s00254-007-0906-4

[15] Marfai, M.A., King, L., Almohammad, H., Dey, S. and Susanto, B. (2008) Coastal Dynamic and Shoreline Mapping: Multi Source Spatial Data Analysis in Semarang, Indonesia. Environmental Monitoring Assessment Journal, 142, 297-308. https://doi.org/10.1007/s10661-007-9929-2

[16] Ongkosongo, O.S.R. (2010) Confluence, Estuary, and Delta. LIPI Pusat Penelitian Oseanografi, Jakarta. (In Bahasa) 
[17] Al Hatrushi, S.M. (2013) Monitoring of the Shoreline Change Using Remote Sensing and GIS: A Case Study of Al Hawasnah Tidal Inlet, Al Batinah Coast, Sultanate of Oman. Arabian Journal of Geosciences, 6, 1479-1484. https://doi.org/10.1007/s12517-011-0424-2

[18] Yilmaz, N., Balas, L. and Inan, A. (2015) Coastal Erosion Problem, Modelling, and Protection. Ocean Science Journal, 50, 589-601. https://doi.org/10.1007/s12601-015-0054-9

[19] Bouchahma, M. and Yan, W. (2014) Monitoring Shoreline Change on Djerba Island Using GIS and Multi-Temporal Satellite Data. Arabian Journal of Geosciences, 7, 3705-3713. https://doi.org/10.1007/s12517-013-1052-9

[20] Tarigan, M.S. (2007) Shoreline Change Analysis in Cisadane Coastal Area, Banten Province. Journal of Makara Sains, 11, 49-55. (In Bahasa)

[21] Kuleli, T. (2010) Quantitative Analysis of Shoreline Changes at the Mediterranean Coast in Turkey. Environmental Monitoring and Assessment, 167, 387-397. https://doi.org/10.1007/s10661-009-1057-8

[22] Anonymous (2012) Medium Term of Demak Regional Development Plan 20112016. Bappeda Kabupaten Demak, Demak.

[23] Marfai, M.A., Tyas, D.W., Nugraha, I., Fitriatul'Ulya, A. and Riasasi, W. (2016) The Morphodynamics of Wulan Delta and Its Impact on the Coastal Community in Wedung Subdistrict, Demak Regency, Indonesia. Journal of Environmental Protection, 7, 60-71. https://doi.org/10.4236/jep.2016.71006

[24] Nandi, S., Ghosh, M. Kundu, A., Dutta, D.W. and Baksi, M. (2016) Shoreline Shifting and Its Prediction Using Remote Sensing and GIS Techniques: A Case Study of Sagar Island, West Bengal, India. Journal of Coastal Conservation, 20, 61-80. https://doi.org/10.1007/s11852-015-0418-4

[25] Ghosh, M.K., Kumar, L. and Roy, C. (2015) Monitoring the Coastline Change of Hatiya Island in Bangladesh Using Remote Sensing Techniques. ISPRS Journal of Photogrammetry and Remote Sensing, 101, 137-144.

[26] Jayson-Quashigah, P.-N., Addo, K.A. and Kodzo, K.S. (2013) Medium Resolution Satellite Imagery as a Tool for Monitoring Shoreline Change. Case Study of the Eastern Coast of Ghana. Journal of Coastal Research, 65, 511-516. https://doi.org/10.2112/SI65-087.1

[27] Ghanavati, E., Firouzabadi, P.Z., Jangai, A.A. and Khosravi, S. (2008) Monitoring Geomorphologic Changes Using Landsat TM and ETM+ Data in the Hendijan River Delta, Southwest Iran. International Journal of Remote Sensing, 29, 945-959. https://doi.org/10.1080/01431160701294679

[28] Marfai, M.A. (2003) GIS Modelling of River and Tidal Flood Hazards in a Waterfront City: Case Study Semarang City, Central Java, Indonesia. M.Sc. Thesis, International Institute for Geo-Information and Earth Observation, ITC, Enschede.

[29] Poro, E. (2011) Analysis of Influence of Waves on Shoreline Change for Optimizing Coastal Tourism of Jepara Regency, Central Java Province, Indonesia. Thesis, Fakultas Geografi Universitas Gadjah Mada, Yogyakarta. (In Bahasa)

[30] Saputra, Q.N. (2011) Shoreline Change and Coastal Dynamic Analysis in Demak Regency, Central Java Province Between 2002 and 2012 in Review of Morphodynamics Aspects. Bachelor Thesis, Fakultas Geografi Universitas Gadjah Mada, Yogyakarta. (In Bahasa)

[31] Winarto, D.A. (2012) Study of Shoreline Analysis in Semarang City and Concept of Countermeasures based on vulnerability Analysis. Thesis, Fakultas Geografi Universitas Gadjah Mada, Yogyakarta. (In Bahasa) 
[32] BPS (2013) Demak Regency in Figures Year 2013. Badan Pusat Statistik Kabupaten Demak, Demak.

[33] Danoedoro, P. (1996) Digital Image Processing. Fakultas Geografi Universitas Gadjah Mada, Yogyakarta. (in Bahasa)

[34] Kasim, F. (2012) Approach Methods in Shoreline Changes Monitoring Using Landsat Remote Sensing Dataset and GIS. Jurnal Ilmiah Agropolitan, 5, 620-635. (In Bahasa)

[35] Fenton, J. (2013) Coastal and Ocean Engineering. TU Wien, Institut Für Wasserbau Und Ingenierurhydrologie.

[36] Mulyadi, Jumarang, M.I. and Apriansyah (2015) Study of High Vulnerability and Significant Sea Wave Periode in Karimata Strait. Jurnal Positron, 5, 19-25.

[37] Rejeki, S. (2011) Management of Eroded Coastal Area in Sayung Subdistrict, Demak Regency, Central Java Province, Indonesia. Thesis, Universitas Diponegoro, Semarang.

[38] Anonymous (2013) The Postgraduate Program of Coastal and Watershed (MPPDAS) Fieldtrip Report. Fakultas Geografi Universitas Gadjah Mada, Yogyakarta.

Submit or recommend next manuscript to SCIRP and we will provide best service for you:

Accepting pre-submission inquiries through Email, Facebook, LinkedIn, Twitter, etc. A wide selection of journals (inclusive of 9 subjects, more than 200 journals)

Providing 24-hour high-quality service

User-friendly online submission system

Fair and swift peer-review system

Efficient typesetting and proofreading procedure

Display of the result of downloads and visits, as well as the number of cited articles

Maximum dissemination of your research work

Submit your manuscript at: http://papersubmission.scirp.org/

Or contact jep@scirp.org 